\title{
Assessment of Water Quality Parameters of Kushiyara River, Bangladesh
}

\author{
Tajmunnaher $^{1}$, Dr. Mohammad Aktarul Islam Chowdhury ${ }^{2}$
}

Department of Civil and Environmental Engineering, Shah Jalal University of Science and Technology (SUST), Sylhet, Bangladesh

\begin{abstract}
The Kushiyara River basin is located in the north eastern region of Bangladesh. The aim of this study is to investigate the water quality parameters seasonal variation on the basis of physico-chemical analysis such as Temperature, $P^{H}$, DO (Dissolved Oxygen), BOD (Biochemical Oxygen Demand), COD (Chemical Oxygen Demand), TS (Total Solids), TDS (Total Dissolved Solids) and SS (Suspended Solids) in both rainy season and winter season for the years 2010 to 2013. The rainy season data is collected during June-July and the winter season data is collected during November-December for each of the year. Our ultimate outcomes will convey a sound message for the government body and policy maker to rules and regulation in order to keep ecological balance as well as save our environment. We therefore suggest wise management of anthropogenic actions in the catchment of Kushiyara River.
\end{abstract}

Keywords: Kushiyara River, Water Quality Parameters, rainy season, winter season, Seasonal Variation, Sylhet.

\section{Introduction}

In the last few decades, the accelerated step of industrial development and progressive growth of population caused in tremendous increase in the demand of fresh water [21]. The quality of surface and groundwater is recognized in terms of its physical, chemical, and biological parameters [15]. The water quality of rivers is categorized by a high level of heterogeneity in time and space, because of the dissimilarity of cover-land around. This habitually creates complications to identify water environments and pollution sources, which is necessary to control effectively pollution in addition to construct successful strategies for minimizing of contamination resources [26]. The rapid increase of population density, land development along river basin, urbanization and industrialization have been endangered for the water quality of rivers. Anthropogenic pollutants related to land use result in radical deterioration of aquatic systems in watersheds [16]. Furthermore, the rivers play an imperative role in assimilating municipal and industrial effluent along with runoff from agricultural land and the surrounding area in a watershed [24]. Alternatively, rivers comprise the most significant water resources for irrigation, domestic water supply, industrial, and other purposes in a watershed, thus tending to stimulate serious hygienic and ecological problems. The prevention and controlling of river pollution and assessment of water quality are an imperative prerequisite for effective management [4], [30]. According to DOE, Malaysia, anthropogenic activities in particular husbandry livestock and agriculture play a significant role in contributing pollution of river water among others pollutants [8]. Wastewater of livestock holds huge concentrations of ammonia nitrogen, organic and inorganic nitrogen compound, and pathogenic bacteria [10]. Additionally, serious environmental damage due to animal waste has been well documented in rivers which receive runoff of nutrient rich waste that caused oxygen reduction and amplified the algae production [1]. In this study an attempt has been taken to examine the seasonal variation of water quality parameters along the Kushiyara River within the years 2010 to 2013.

\section{Material and Method}

\section{A.Description of Study Area}

Sylhet is the Divisional city of North Eastern Region of Bangladesh [28], and the Kushiyara River is one of the important rivers of this region which has got a multipart river system that supports a diversity of uses, comprising irrigation systems in agricultural lands, drinking water and industries wastewater. The effluents from all these sources is directly discharged into the river. Kushiyara River one of the transboundary rivers of Bangladesh. The Barak River enters Bangladesh along $24^{\circ} 53^{\prime}$ north latitudes and $92^{\circ} 32^{\prime}$ east longitudes. The Barak splits into two branches at Amalshid in the northeast border of Zakiganj Upozila of Sylhet district. The northwest part is the Surma and the southwestern part is the Kushiyara. At Amalshid, the bed of the Surma has to a large extent dried up and as a result, about 85 percent flow of the Barak runs through the Kushiyara. The total length of the Kushiyara River is about $161 \mathrm{~km}$ and the average width of the river is $250 \mathrm{~m}$. In the rainy season the mean depth of the Kushiyara reaches up to $10 \mathrm{~m}$. The river carries an enormous amount of water with sediments from Karimganj of Assam and the hilly areas of Hill Tripura. The river passes over Zakiganj, Golabganj, Fenchuganj, Balaganj, Rajnagar, Maulvibazar and Nabiganj. The Fenchuganj Fertilizer Factory stands on the bank of the Kushiyara [13]. The study area is shown figure 1 .

\section{B.Sampling and Analysis}

Water samples were collected from the Kushiyara River from upstream to downstream along the river during two seasonsnamely rainy season and winter season, and tested for some physical and chemical water quality parameters which are required for this study. Water samples were collected for the years 2010, 2011, 2012 and 2013 consequently. For first two years 15 sampling points are taken and for the years 2012 and 2013, 20 sampling stations are taken along the rivers for both seasons. The sampling station name are shown in table 1. Water sample from various point in Kushiyara River was collected and routine laboratory analysis made for physical

Volume 6 Issue 12, December 2017 


\section{International Journal of Science and Research (IJSR) \\ ISSN (Online): 2319-7064}

Index Copernicus Value (2016): 79.57 | Impact Factor (2015): 6.391

and chemical qualities according to the standard method [2] in the Water Supply and Sewerage Engineering Laboratory of Civil and Environmental Engineering Department, Shah Jalal University of Science and Technology, Sylhet, Bangladesh.
Table 1: Sampling stations of Kushiyara River

\begin{tabular}{|c|c|c|c|}
\hline Station no & Station Name & Station no & Station Name \\
\hline 1 & Amolshid Trimuhona & 11 & Manik Kona Bazar \\
\hline 2 & Jakiganj-1 & 12 & Sunampur \\
\hline 3 & Jakiganj-2 & 13 & Fenchuganj \\
\hline 4 & Jakiganj-3 & 14 & East Gouripur \\
\hline 5 & Jakiganj-4 & 15 & Balaganj Bus-stand \\
\hline 6 & Dobagh Bazar & 16 & Rajnagar \\
\hline 7 & Sheola Bazar & 17 & East Pailanpur \\
\hline 8 & Sheola & 18 & Janater Bazar \\
\hline 9 & Kurar Bazar & 19 & Khasrupur \\
\hline 10 & Budhbari Bazar & 20 & Shadin Bazar \\
\hline
\end{tabular}

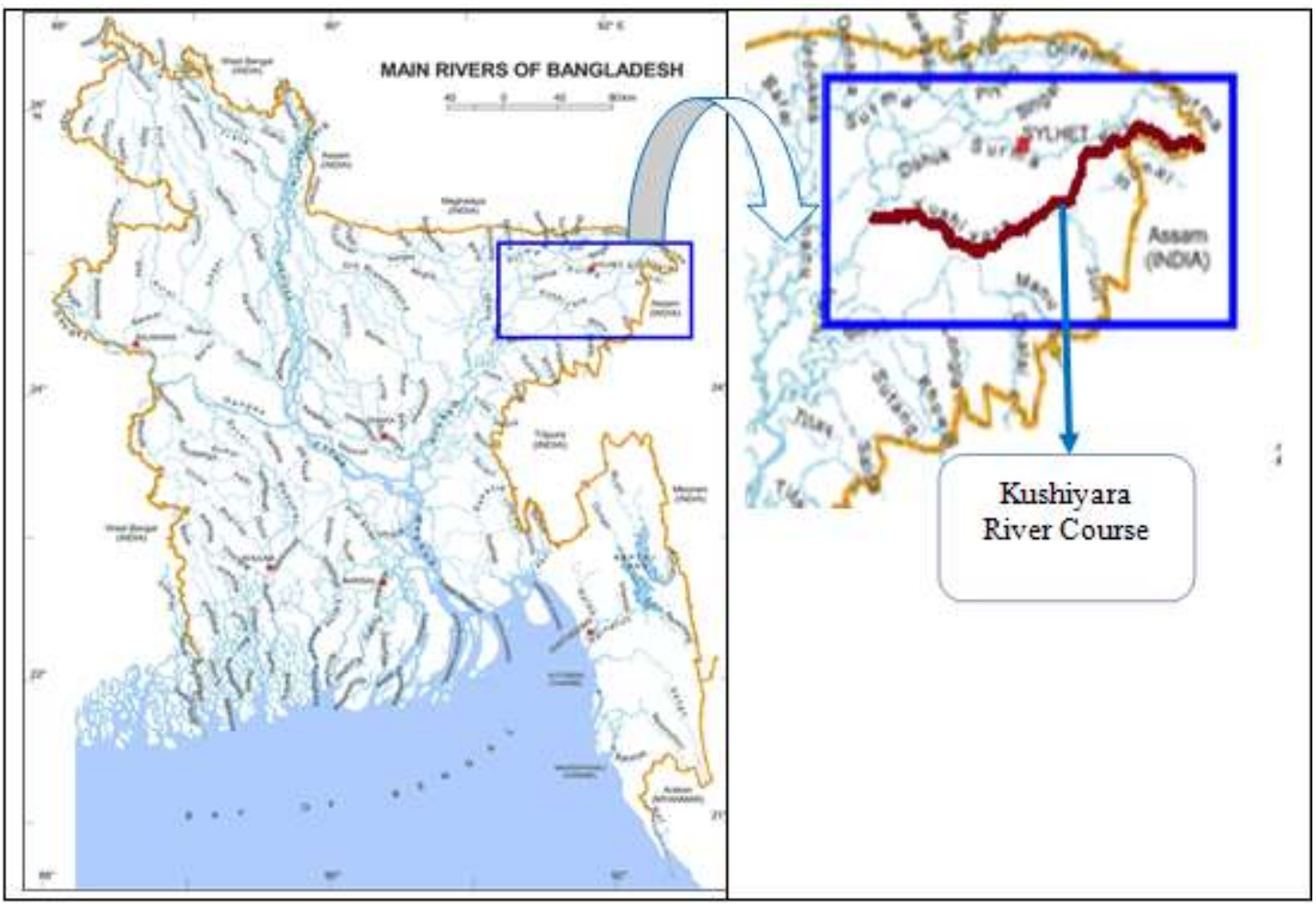

Figure 1: Kushiyara River basin Modified after source [22].

\section{C.Water Quality Parameters general information}

Temperature is an important parameter in characterization of natural water bodies. It affects the water chemistry such as saturation and concentration of dissolved gases, especially oxygen [19]. The rate of chemical reactions generally increases as temperature increases (rule of Vant Hoff). Temperature also affects biological activity and regulates the kinds of organisms that can live in the lake. The most obvious reason for temperature change in lakes is the change in seasonal air temperature [7]. Temperature is a critical water quality and environmental parameter because it governs the kinds and types of aquatic life, regulates the maximum dissolved oxygen concentration of the water, and influences the rate of chemical and biological reactions [18]. $\mathrm{P}^{\mathrm{H}}$ is a very important factor that must be considered to determine for water quality. The $\mathrm{P}^{\mathrm{H}}$ of any water body surface is defined as a measure of Hydrogen ion concentration. In other words, $\mathrm{P}^{\mathrm{H}}$ is a measure of the alkalinity or acidity of water soluble substances [6], [31]. Dissolved Oxygen (DO) is defined as the amount of oxygen dissolved in a water body and measures the health of the water and its ability to support a balance aquatic ecosystem [29], [17]. The DO appears as microscopic bubbles of gaseous oxygen which are mixed in water and available to aquatic organisms for respiration [11], [17]. BOD (Biochemical Oxygen Demand) is defined as the amount of oxygen required by aerobic microorganisms to dissolve organic matter in a sample of water. It is one of the most essential and widely used parameters for the most essential and widely used parameters for measuring pollutants and biodegradable organic compounds in water [14], [25], [17]. Low the BOD, higher the desirability of using for human use, like drinking \& domestic purposes. BOD has been used as a measure of the amount of organic materials in an aquatic solution which support the growth of microorganisms [5]. For drinking water, BOD should be nil. The COD is the amount of specified oxidant that reacts with a sample of water under controlled conditions and is expressed in terms of oxygen equivalence [17], [27]. COD is viewed as a useful measure of water quality because its application determines the amount of organic pollutants present in surface water or wastewater [32]. Total solids includes both total suspended solids, the portion of total solids retained by a filter and total dissolved solids, the portion that passes through a filter [12]. The total amount of all dissolved solutes and silica present in a water body is recognized as the total dissolved solids

\section{Volume 6 Issue 12, December 2017}

\section{www.ijsr.net}




\section{International Journal of Science and Research (IJSR) \\ ISSN (Online): 2319-7064 \\ Index Copernicus Value (2016): 79.57 | Impact Factor (2015): 6.391}

(TDS). TDS are mainly the inorganic minerals and sometimes some organic matter. It can be determined gravimetrically by evaporating a known volume of water and measuring the mass of the residue left [3]. Suspended solid (SS) are the solid matter suspended in water, comprising of organic and inorganic materials, such as plankton, silt and industrial waste [9], [17].

\section{Result and Discussion}

The fluctuation of temperature at different times and locations of Kushiyara River are presented in figure 2. The rainy season data for all the years is shown in left side and winter season data is shown in right side of the figure. The average rainy season water temperature for the years 2010 , 2011,2012 and 2013 are $26.21^{\circ} \mathrm{C}, 26.65^{\circ} \mathrm{C}, 26.04^{\circ} \mathrm{C}$ and $26.78^{\circ} \mathrm{C}$ respectively. The average winter season temperature for the years 2010 to 2013 are $24.62^{\circ} \mathrm{C}, 24.73^{\circ} \mathrm{C}, 24.36^{\circ} \mathrm{C}$ and $25.13^{\circ} \mathrm{C}$ respectively. The maximum and minimum rainy season temperature are $28.03^{\circ} \mathrm{C}$ at Jakijanj-4 in the year 2013 and $25^{\circ} \mathrm{C}$ at Jakijanj-3 in the year 2012 . The maximum and minimum winter season temperature are $26.82^{\circ} \mathrm{C}$ at Janatar Bazar in the year 2013 and $23.12^{\circ} \mathrm{C}$ at Jakijanj-1 in the year 2010. The results of $\mathrm{P}^{\mathrm{H}}$ for rainy seasons and winter seasons are shown in figure 3 . The average rainy season $\mathrm{P}^{\mathrm{H}}$ for the years 2010, 2011, 2012 and 2013 are 6.77, 6.58, 6.66 and 6.72 respectively. The average winter season $\mathrm{P}^{\mathrm{H}}$ for the years 2010 to 2013 are $6.44,6.53,6.30$ and 6.37 respectively. The maximum rainy season $\mathrm{P}^{\mathrm{H}}$ is 7.31 at Jakijanj-3 in the year 2013 and the maximum winter season $\mathrm{P}^{\mathrm{H}}$ is 7.3 at Jakiganj-1 in the year 2012 and 2013. In winter season the maximum $\mathrm{P}^{\mathrm{H}}$ value is 6 at East Gouripur (2010) and Janatar Bazar (2013) and minimum value is 5.85 at Kurer Bazar in the year 2013. The test results of DO for rainy seasons and winter seasons are shown in figure 4 . The average rainy season DO for the years 2010, 2011, 2012 and 2013 are 7.33, 10.93, 8.19 and $7.32 \mathrm{mg} / \mathrm{l}$ respectively. The average winter season DO for the years 2010 to 2013 are $5.25,7.36,6.85$ and $6.20 \mathrm{mg} / \mathrm{l}$ respectively. The maximum rainy season DO is $12.2 \mathrm{mg} / \mathrm{l}$ at Manik Kona Bazar in the year 2011 and the minimum rainy season DO is $4.5 \mathrm{mg} / \mathrm{l}$ at Sheola Bazar in the year 2010. The maximum winter season DO is $8.6 \mathrm{mg} / \mathrm{l}$ at Manik Kona Bazar in the year 2011 and the minimum winter season DO is $3.1 \mathrm{mg} / \mathrm{l}$ at Rajnagar in the year 2013. However water of Kushiyara River is deteriorating from the view point of DO.

The test results of BOD are presented in figure 5. The average rainy season BOD for the years 2010, 2011, 2012 and 2013 are $5.11,5.13,5.61$ and $5.44 \mathrm{mg} / \mathrm{l}$ respectively. The average winter season BOD for the years 2010 to 2013 are $4.12,4.18,4.41$ and $4.33 \mathrm{mg} / 1$ respectively. The maximum rainy season BOD is 7.40 at East Pailanpur in the year 2012 and the minimum rainy season BOD is $3.9 \mathrm{mg} / \mathrm{l}$ at Kurer Bazar in the year 2012. The maximum winter season BOD is $6.2 \mathrm{mg} / \mathrm{l}$ at East Gouripur in the year 2012 and the minimum winter season BOD is $2.8 \mathrm{mg} / \mathrm{l}$ at Jakiganj-4 in the year 2012 . The average rainy season COD for the years 2010, 2011, 2012 and 2013 are 6.63, 6.65, 6.77 and $6.84 \mathrm{mg} / \mathrm{l}$ respectively. The results of COD for rainy seasons and winter seasons are shown in figure 6 . The average winter season COD for the years 2010 to 2013 are 6.05, 6.08, 6.12 and 6.16 $\mathrm{mg} / \mathrm{l}$ respectively. The maximum and minimum rainy season COD are $8.40 \mathrm{mg} / \mathrm{l}$ at Manik Kona Bazar in the year 2013 and $5.60 \mathrm{mg} / \mathrm{l}$ at Janatar Bazar in the year 2013. The maximum winter season COD is $8.20 \mathrm{mg} / \mathrm{l}$ at Balaganj Busstand in the year 2012 and the minimum winter season COD is found $5.50 \mathrm{mg} / \mathrm{l}$ at Balaganj Bus-stand (2010) and Dobagh Bazar (2011). The test results of TS for rainy seasons and winter seasons are shown in figure 7 . The average rainy season TS for the years 2010, 2011, 2012 and 2013 are 208.93, 210.07, 228.77 and $240.55 \mathrm{mg} / \mathrm{l}$ respectively. The average winter season TS for the years 2010 to 2013 are 206.87, 219.73, 217.55 and $233.30 \mathrm{mg} / \mathrm{l}$ respectively. The maximum rainy season TS is $306.00 \mathrm{mg} / \mathrm{l}$ at Jakiganj-4 in the year 2013 and maximum winter season TS is $287.00 \mathrm{mg} / \mathrm{l}$ at Sheola Bazar in the year 2013. The minimum rainy season TS is $166.00 \mathrm{mg} / \mathrm{l}$ at East Pailanpur in the year 2013 and minimum winter season TS is $165.00 \mathrm{mg} / \mathrm{l}$ at Jakiganj-4 in the year 2011. The results of TDS for rainy seasons and winter seasons are shown in figure 8 . The average rainy season TDS for the years 2010, 2011, 2012 and 2013 are $116.20,123.27,135.38$ and $141.20 \mathrm{mg} / \mathrm{l} \mathrm{respectively.} \mathrm{The}$ average winter season TDS for the years 2010 to 2013 are $119.33,125.53,123.45$ and $136.60 \mathrm{mg} / \mathrm{l}$ respectively. The maximum and minimum rainy season TDS are $193.00 \mathrm{mg} / \mathrm{l}$ at Budhbari Bazar in the year 2012 and $90.00 \mathrm{mg} / \mathrm{l}$ at Sheola Bazar in the year 2011 respectively. The maximum and minimum winter season TDS are $187.00 \mathrm{mg} / \mathrm{l}$ at Manik Kona Bazar in the year 2012 and $87.00 \mathrm{mg} / \mathrm{l}$ at Jakiganj-4 (2011). The test results of SS for rainy seasons and winter seasons are shown in figure 9. The average rainy season SS for the years 2010, 2011, 2012 and 2013 are 93.53, 84.47, 93.45 and $99.35 \mathrm{mg} / \mathrm{l}$ respectively. The average winter season SS for the years 2010 to 2013 are $87.53,94.73,94.10$ and 96.70 $\mathrm{mg} / \mathrm{l}$ respectively. The maximum and minimum rainy season SS are $133.00 \mathrm{mg} / \mathrm{l}$ at Fenchujang (2013) and $43.00 \mathrm{mg} / \mathrm{l}$ at Budhbari Bazar (2011) .and $87.00 \mathrm{mg} / \mathrm{l}$ at Jakiganj-4 (2011). The maximum and minimum winter season SS are 128.00 $\mathrm{mg} / \mathrm{l}$ at Sheola Bazar (2013) and $44.00 \mathrm{mg} / \mathrm{l}$ at Jakiganj-4 (2010).

Volume 6 Issue 12, December 2017 www.ijsr.net 


\section{International Journal of Science and Research (IJSR) \\ ISSN (Online): 2319-7064}

Index Copernicus Value (2016): 79.57 | Impact Factor (2015): 6.391

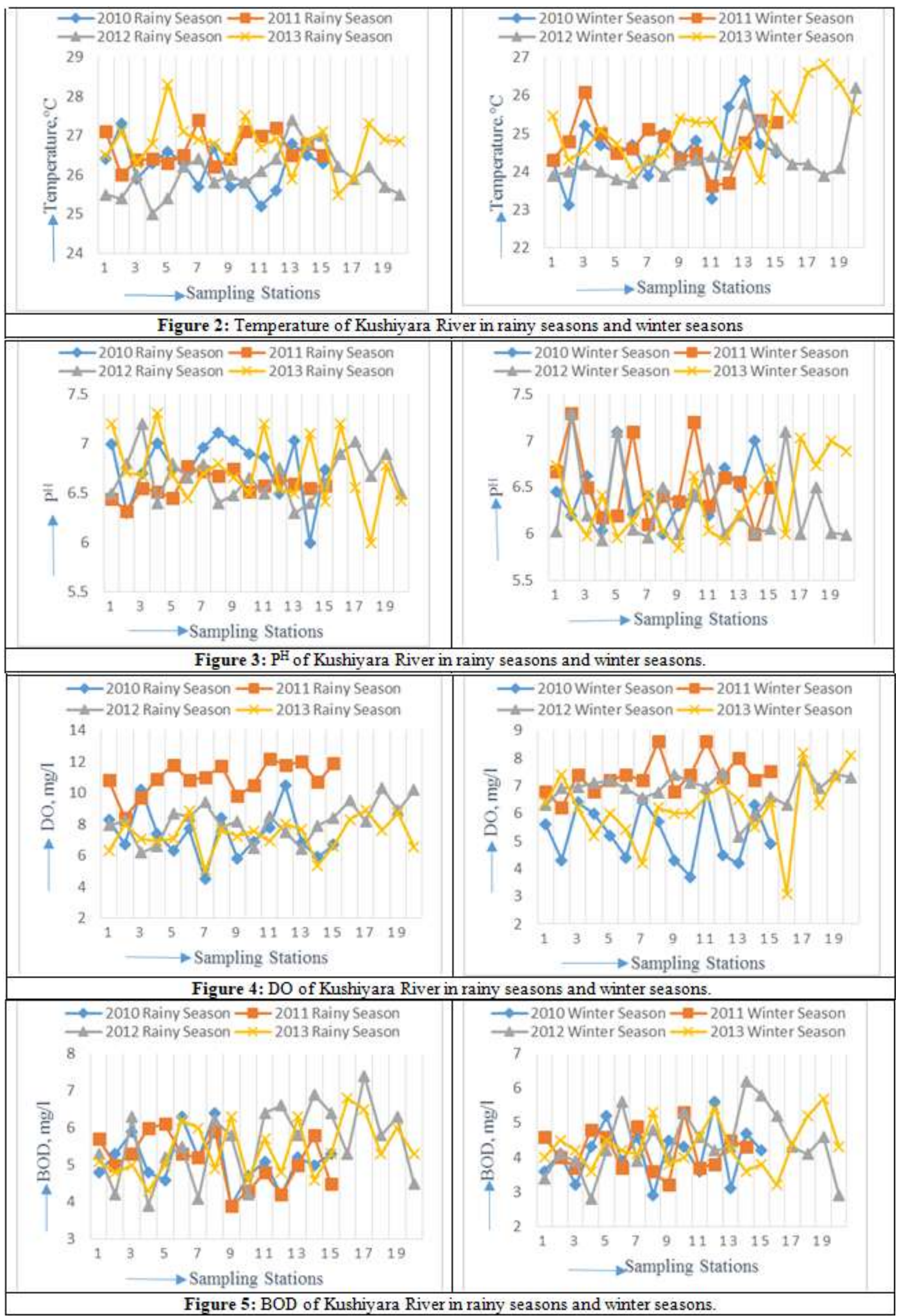

Volume 6 Issue 12, December 2017

www.ijsr.net

Licensed Under Creative Commons Attribution CC BY 


\section{International Journal of Science and Research (IJSR) \\ ISSN (Online): 2319-7064}

Index Copernicus Value (2016): 79.57 | Impact Factor (2015): 6.391

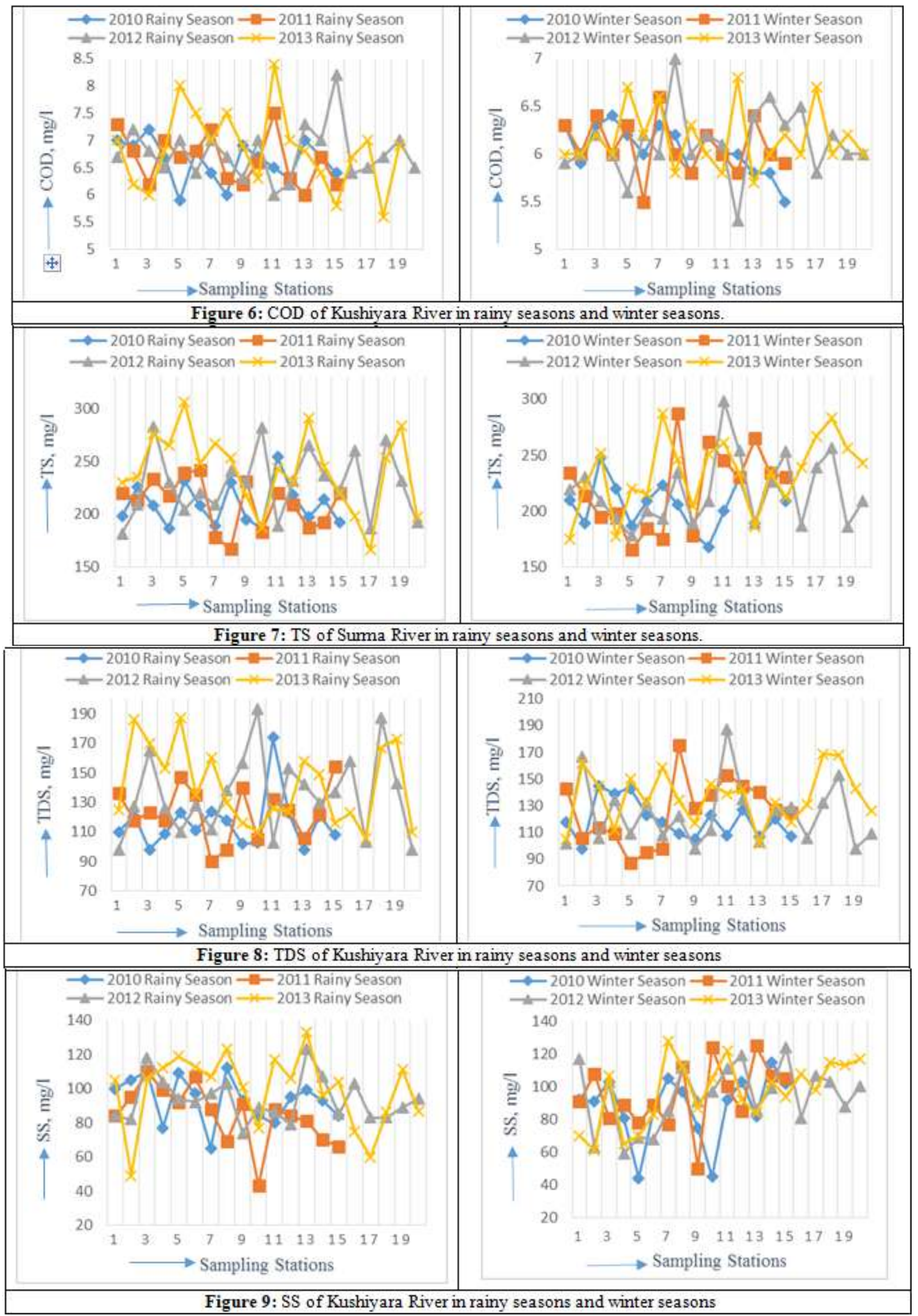

Volume 6 Issue 12, December 2017

www.ijsr.net

Licensed Under Creative Commons Attribution CC BY 


\section{International Journal of Science and Research (IJSR) \\ ISSN (Online): 2319-7064}

Index Copernicus Value (2016): 79.57 | Impact Factor (2015): 6.391

Sarwar et al., (2010) evaluated effects of wastes on the Physico-chemical characteristics of the Karnafully River due to presence of many chemical fertilizers, iron, leather and pharmaceutical industries [23]. From the finding of the result they concluded that river Karnafully was losing its water quality day by day and the river was under severe pollution threat. Rajkumar et al., (2013) found that the Barak River have been contaminated with waterborne pathogenic bacteria because of increased anthropogenic and socio-cultural activities at different sites of the Barak River and also by sewage, faecal contaminants and industrial wastes and the water of the Barak River is not suitable for drinking and other recreational purposes [20]. As the Barak River is the source of Kushiyara River from India and the water of this river is polluted day by day. Therefore the Kushiyara River water quality is deteriorated.

\section{Conclusion}

This study was conducted to measure the magnitude of environmental pollution considering seasonal variations of surface river water quality. The water quality in rainy season and winter season is controlled by mixed origin of natural, wastewater discharges and surface runoff. The analysis reveals that temperature values are in increasing trend from 2010 to 2013 in both seasons without the value in the year 2012. There is no abrupt change in $\mathrm{P}^{\mathrm{H}}$ value occurred from the study. The average DO for the year 2010 was less than 2011 for both the season but from 2011 to 2013 the value is decreasing at an alarming rate for both season which will create serious problem for the aquatic organisms. It is also observed that the BOD, COD, TS, TDS and SS values are also increasing with respect to time. Finally on the basis of monitoring of selected physico-chemical parameters in the last four years, undoubtedly it can be conclude that the Kushiyara River water quality is deteriorating with time. The causes behind this is that along its course the Kushiyara River receives many types of point and non-point sources pollutants from Cement factory, agricultural fertilizers residue, municipal waste, rural markets discharges, detergents from washing cloth and bathing, human faces from slum areas of the cities etc. Therefore, recovery process of the river water quality must start immediately.

\section{References}

[1] Anon, "Water Effluent from Pig Farms in Sabah-A Preliminary investigation of the Key Environmental Issue", State Environmental Conservation Department, Sabah, Malaysia, 2001.

[2] APHA-AWWA-WPCF, 1998, "Standard methods for the examination of water and wastewater", 19th edn. American Public Health Association, Washington.

[3] Ambasht, R.S., and Ambasht, P.K., 1999, "Environment and Pollution an ecological approach". Third Edition, CBS publishers and Distributors.

[4] Chen, Y.W., Fan, C.X., Teubner, K., and Dokulil, M., 2003, "Changes of nutrients and phytoplankton chlorophyll-a in a large shallow lake, Taihu, China: an 8year investigation". Hydrobiologia, vol. 506-509, pp. 273-279.
[5] Ciaccio, L., 1971, "Water and water pollution". Vol. I. New York: Marcel Dekker, Inc.

[6] Covington, A.K., Whalley, P.D., and Davison, W., 1985, "Recommendations for the determination of $\mathrm{PH}$ in low ionic strength fresh waters". Pure and Applied Chemistry, Vol. 57, Issue. 6, pp. 877-886.

[7] David C.L.M., and Schertzer, W.M., 1999, "Potential climate change effects on Great Lakes hydrodynamics and water quality," Ed. ASCE Publications. 232 p

[8] DOE, Malaysia Environmental Quality Report, Department of Environment, Ministry of Science, Technology and Environment Maskha Sdn Bhd, Kuala Lumpur, Malaysia, 2001.

[9] Ell, M.J., 2008, “Total suspended solids (TSS). In N. D. D. O. Health (Ed.)". Northg Dakotan, USA.

[10] Gasim, M.B., Jamil, M.M., Rahim, S.A., and Toriman, M.E., 2009, "Water-quality assessment of the Langat River at kilometre 7, Jalan Kajang-Bangi, Selangor, Malaysia". Arab World Geographer, vol. 12, no. 3-4, pp. 188-198.

[11] Ji, Z.G., 2008, "Hydrodynamics and water quality: modelling rivers, lakes and estuaries". WileyInterscience.

[12] Kar, S.R., and Chowdhury, M.I.U., 2013, "Water quality analysis of Kushiyara River". B.Sc. Engineering Thesis, Civil and Environmental Engineering Department, Shah Jalal University of Science and Technology, Sylhet, Bangladesh.

[13] Kushiyara-River, Banglapedia, 2014. Available: http://en.banglapedia.org/index.php?title=Kushiyara_Riv er

[14] Kwok, N.Y., Dong, S., Lo, W., and Wong, K.Y., 2005, "An optical biosensor for multi-sample determination of biochemical oxygen demand (BOD)". Sensors and Actuators B: Chemical, Vol. 110, Issue. 2, pp. 289-298.

[15] Loukas, A., 2010, "Surface water quantity and quality assessment in Pinios River, Thessaly, Greece". Desalination, vol. 250, no. 1, pp. 266-273.

[16] Massoud, M.A., El-Fadel, M., Scrimshaw, M.D., and Lester, J.N., 2006, "Factors influencing development of management strategies for the Abou Ali River in Lebanon. I: spatial variation and land use". Science of the Total Environment, vol. 362, no. 1-3, pp. 15-30.

[17] Mohammed, I., Othman, F., Ibrahim, A.I.N., Alaa-Eldin, M.E., and Yunus, R.M., 2015, “Assessment of water quality parameters using multivariate analysis for Klang River basin, Malaysia”. Enviro Monit Assess, 187:4182

[18] Oram, P.G., 2017, Available: www.waterresearch.net/index.php/stream-water-quality-importanceof-temperature.

[19] Quagliano, J.V., and Vallarino, L.M., 1969, “Chemistry. Ed.," Prentice-Hall, University of California. 844p

[20] Rajkumar, B., and Sharma, G.D., 2013, "Seasonal bacteriological analysis of Barak River, Assam, India". Appl Water Sci., Vol. 3, pp. 625-630.

[21] Ramakrishnaiah, C.R., Sadashivaiah, C., and Ranganna, G., 2009, "Assessment of water quality index for the groundwater in Tumkur taluk, Karnataka state, India”. EJournal of Chemistry, vol. 6, no. 2, pp. 523-530.

[22] Rivers of Bangladesh, Sep. 2017, Available: Source: http://www.thebangladesh.net/rivers-of-bangladesh 
[23] Sarwar, M.I., Majumdar, A.K., and Islam, M.N., 2010, "Water Quality Parameters: A case Study of Karnafully River Chittagong, Bangladesh". Bangladesh J. Sci. Ind. Res. 45(2), pp. 177-181.

[24] Sigua, G.C., and Tweedale, W.A., 2003, "Watershed scale assessment of nitrogen and phosphorus loadings in the Indian River Lagoon basin, Florida". Journal of Environmental Management, vol. 67, no. 4, pp. 363372.

[25] Simon, F.X., Penru, Y., Guastalli, A.R., Llorens, J., and Baig, S., 2011, "Improvement of the analysis of the biochemical oxygen demand (BOD) of Mediterranean seawater by seeding control”. Talanta, Vol. 85, Issue. 1, pp. 527-532.

[26] Singh, K.P., Malik, A., and Sinha, S., 2005, "Water quality assessment and apportionment of pollution sources of Gomti river (India) using multivariate statistical techniques-a case study". Analytica Chimica Acta, vol. 538, no. 1-2, pp. 355-374.

[27] Singh, K.P., Malik, A., Mohan, D., and Sinha, S., 2004, "Multivariate Statistical Techniques for the evaluation of spatial and temporal variations in quality of Gomti river (India) using multivariate statistical techniques: a case study". Water Research 38, pp. 3980-3992.

[28] SylhetCityCorporation,2014, (http://www.sylhetcitycorporationbd.org/index.php/cms/ about_sylhet/)

[29] Synder, J., 2007, Dissolved Oxygen Available: http://www.seagrant.sunysb.edu/oil/water\%20Quality/Di ssolvedQxygen.html2013

[30] Tripathi, B.D., Sikandar, M., and Shukla, S.C., 1989, "Physico-chemical characterization of city sewage discharged into river Ganga at Varanasl, india". Centre of Advanced Study in Botany, Banaras Hindu University, Varanasi - 221005 , India.

[31] Vassilis, Z.A., Papamichail, D.M., and Mitsiou, K.A., 2001, "Statistical and trend analysis of water quality and quantity data for the strymon River in Greece". Hydrology and Earth System Science, Vol. 5, Issue. 4, pp. 679-691.

[32] Viessman, W., and Hammer, M.J., 2005, "Water supply and pollution control (7th edn.)". The University of Michigan. USA: Pearson Prentice Hall.

\section{Author Profile}

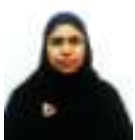

Tajmunnaher is $\mathrm{PhD}$ Research Fellow and Faculty Member, Department of Civil and Environmental Engineering, Shahjalal University of Science and Technology, Sylhet, Bangladesh.

Dr. Mohammad Aktarul Islam Chowdhury is Faculty Member, Department of Civil and Environmental Engineering, Shahjalal University of Science and Technology, Sylhet, Bangladesh. 